\title{
Effort-Related Motivational Effects of the VMAT-2 Inhibitor Tetrabenazine: Implications for Animal Models of the Motivational Symptoms of Depression
}

\author{
Eric J. Nunes, ${ }^{1}$ Patrick A. Randall, ${ }^{1}$ Evan E. Hart, ${ }^{1}$ Charlotte Freeland, ${ }^{1}$ Samantha E. Yohn, ${ }^{1}$ Younis Baqi, ${ }^{2}$ \\ Christa E. Müller, ${ }^{2}$ Laura López-Cruz, ${ }^{3}$ Mercè Correa, ${ }^{1,3}$ and John D. Salamone ${ }^{1}$ \\ ${ }^{1}$ Department of Psychology, University of Connecticut, Storrs, Connecticut 06269-1020, ${ }^{2}$ Universität Bonn, Pharma-Zentrum Bonn, Pharmazeutisches \\ Institut, Pharmazeutische Chemie, 53121 Bonn, Germany, and ${ }^{3}$ Àrea de Psicobiologia, Campus de Riu Sec, Universitat Jaume I, 12071 Castelló, Spain
}

\begin{abstract}
Motivated behaviors are often characterized by a high degree of behavioral activation, and work output and organisms frequently make effort-related decisions based upon cost/benefit analyses. Moreover, people with major depression and other disorders often show effort-related motivational symptoms such as anergia, psychomotor retardation, and fatigue. It has been suggested that tasks measuring effort-related choice behavior could be used as animal models of the motivational symptoms of depression, and the present studies characterized the effort-related effects of the vesicular monoamine transport (VMAT) inhibitor tetrabenazine. Tetrabenazine produces depressive symptoms in humans and, because of its selective inhibition of VMAT-2, it preferentially depletes dopamine (DA). Rats were assessed using a concurrent fixed-ratio 5/chow feeding choice task that is known to be sensitive to dopaminergic manipulations. Tetrabenazine shifted response choice in rats, producing a dose-related decrease in lever pressing and a concomitant increase in chow intake. However, it did not alter food intake or preference in parallel free-feeding choice studies. The effects of tetrabenazine on effort-related choice were reversed by the adenosine $\mathrm{A}_{2 \mathrm{~A}}$ antagonist MSX-3 and the antidepressant bupropion. A behaviorally active dose of tetrabenazine decreased extracellular DA in nucleus accumbens and increased expression of DARPP-32 in accumbens medium spiny neurons in a pattern indicative of reduced transmission at both $\mathrm{D}_{1}$ and $\mathrm{D}_{2} \mathrm{DA}$ receptors. These experiments demonstrate that tetrabenazine, which is used in animal models to produce depression-like effects, can alter effort-related choice behavior. These studies have implications for the development of animal models of the motivational symptoms of depression and related disorders.
\end{abstract}

Key words: decision making; vigor; motivation; negative symptoms; basal ganglia; DAT inhibitor

\section{Introduction}

To survive, organisms must overcome obstacles separating them from motivational stimuli and make effort-related decisions based upon cost/benefit analyses (Salamone and Correa, 2002, 2012). There is considerable interest in characterizing the neural circuitry underlying effort-based processes in animals (Salamone et al., 1997, 2007; Walton et al., 2003; Cagniard et al., 2006; Floresco and Ghods-Sharifi, 2007; Mingote et al., 2008; Hauber and Sommer, 2009; Salamone and Correa, 2012; Nunes et al., 2013a;

Received June 27, 2013; revised Oct. 11, 2013; accepted 0ct. 15, 2013.

Author contributions: E.N., P.R., M.C., and J.D.S. designed research; E.N., P.R., E.H., C.F., and S.E.Y. performed research; Y.B. and C.M. contributed unpublished reagents/analytic tools; E.N., P.R., E.H., C.F., L.L.C., M.C., and J.D.S. analyzed data; E.N., C.M., M.C., and J.D.S. wrote the paper.

This work was supported by the National Institutes of Health-National Institute of Mental Health (Grant MH094966 to J.D.S.), Fundació Bancaixa/U. Jaume I. (Grant P1.1B2010 - 43 to M.C.), and a Student Undergraduate Research Fellowship grant to C.F. We thank Matthew Eastman and Joanne Conover for their help with the microscopy.

J.D.S. has received grants from Merck-Serrono, Pfizer, and Roche and is a consultant for Merz. The remaining authors declare no competing financial interests.

Correspondence should be addressed to John D. Salamone, PhD, Board of Trustees Distinguished Professor, Head, Division of Behavioral Neuroscience, Dept. of Psychology, University of Connecticut, Storrs, CT 06269-1020. E-mail: john.salamone@uconn.edu.

DOI:10.1523/JNEUROSCI.2730-13.2013

Copyright $\odot 2013$ the authors $\quad 0270-6474 / 13 / 3319120-11 \$ 15.00 / 0$
Pasquereau and Turner, 2013) and humans (Croxson et al., 2009; Kurniawan et al., 2010; Wardle et al., 2011; Treadway et al., 2012a). Effort-based decision making is studied with tasks offering choices between high effort options leading to highly valued reinforcers versus low effort/low reward options. In animal studies, such tasks include operant procedures offering choices between responding on ratio schedules for preferred reinforcers versus approaching and consuming a less preferred food (Salamone et al., 1991, 2002; Randall et al., 2012), a T-maze barrier crossing task (Salamone et al., 1994; Mott et al., 2009; Pardo et al., 2012), and effort discounting (Floresco et al., 2008; Bardgett et al., 2009). Considerable research has focused on the effort-related functions of dopamine (DA) systems, particularly accumbens DA. Across multiple tasks, low doses of DA antagonists and accumbens DA depletions or antagonism shift choice behavior, decreasing selection of high effort/high reward options, and increasing selection of low effort/low reward choices (Salamone et al., 1994, 1997, 2007; Nowend et al., 2001).

People with depression and related disorders commonly show profound motivational impairments, including psychomotor retardation, anergia, lassitude, and fatigue, which can be highly resistant to treatment (Stahl, 2002; Bella et al., 2010). Tasks measuring effortbased functions have been suggested as potential models for these 
motivational symptoms (Salamone et al., 2006, 2007). Tests of effort-related decision making have been developed in humans (Treadway et al., 2009), and depressed patients show reduced selection of high effort alternatives (Treadway et al., 2012b). The present work investigated the effort-related effects of tetrabenazine, a selective and reversible inhibitor of vesicular monoamine transporter-2 (VMAT-2). Tetrabenazine blocks storage and depletes monoamines, but its greatest impact is upon striatal DA (Pettibone et al., 1984; Tanra et al., 1995). Tetrabenazine is used to treat Huntington's disease, but depressive symptoms including fatigue are major side effects (Frank, 2009, 2010). Moreover, tetrabenazine has frequently been used in studies involving animal models of depression (Preskorn et al., 1984; Kent et al., 1986; Wang et al., 2010). The present studies assessed the effort-related effects of tetrabenazine in rats using the concurrent fixed ratio 5 (FR5) lever-pressing/chow-feeding choice task (Salamone et al., 1991, 2002, 2009). It was hypothesized that low systemic doses and intra-accumbens injections of tetrabenazine would alter choice behavior, decreasing lever pressing but increasing consumption of the concurrently available chow. The adenosine $\mathrm{A}_{2 \mathrm{~A}}$ antagonist MSX-3 [ $(E)$-phosphoric acid mono-[3[8-[2-(3-methoxyphenyl)vinyl]-7-methyl-2,6-dioxo-1-prop-2ynyl-1,2,6,7-tetrahydropurin-3-yl]propyl] ester disodium salt]and the antidepressant bupropion were assessed for their ability to reverse the effects of tetrabenazine. Additional studies determined the effect of tetrabenazine on extracellular DA using microdialysis methods and DA-related signal transduction activity using immunocytochemistry for phosphorylated DARPP-32.

\section{Materials and Methods}

Animals

Adult male Sprague Dawley rats (Harlan-Sprague Dawley) were pair housed in a colony maintained at $23^{\circ} \mathrm{C}$ with $12 \mathrm{~h} \mathrm{light/dark} \mathrm{cycles} \mathrm{(lights}$ on at 7:00 h). Rats $(N=129)$ weighed $290-340 \mathrm{~g}$ at the beginning of the study and were initially food restricted to $85 \%$ of their free-feeding body weight for operant training. Rats were fed supplemental chow to maintain the food restriction throughout the study, given water ad libitum, and allowed modest weight gain throughout the experiments. Animal protocols were approved by the University of Connecticut institutional animal care and use committee and followed National Institutes of Health guidelines.

\section{Pharmacological agents}

Tetrabenazine $[(R, R)$-3-Isobutyl-9,10-dimethoxy-1,3,4,6,7,11b-hexahydro-pyrido[2,1-a]isoquinolin-2-one] and bupropion [(RS)-1-(3-chlorphenyl)-2-tert-butylamino-propan-1-on hydrochloride] were obtained from Tocris Bioscience. Tetrabenazine was dissolved in a 10\% dimethyl sulfoxide (DMSO) solution mixed with saline and $\mathrm{pH}$ adjusted with $1 \mathrm{~N} \mathrm{HCl}$ to bring the final solution to $\mathrm{pH} 3.5$. The $10 \%$ DMSO solution used to dissolve the tetrabenazine served as the vehicle control. Doses of tetrabenazine used were based on previous data and pilot studies. Bupropion was dissolved in $0.9 \%$ saline. MSX-3 was provided by Christa Müller at the Pharmazeutisches Institut, Universität Bonn, in Bonn, Germany (Hockemeyer et al., 2004). MSX-3 (free acid) was dissolved in $0.9 \%$ saline and $\mathrm{pH}$ was adjusted by titrating with microliter quantities of $1.0 \mathrm{~N} \mathrm{NaOH}$ until the drug was in solution. The final $\mathrm{pH}$ was usually $7.5 \pm 0.2$ and was not allowed to exceed 7.8. Doses were selected based upon pilot experiments and previous studies; the doses of MSX-3 selected have been shown previously to reverse DA antagonist-induced impairments in FR5 lever pressing and effort-related choice (Farrar et al., 2007; Worden et al., 2009), but did not affect FR5/chow-feeding performance when administered alone (Farrar et al., 2007).

\section{Behavioral procedures}

Behavioral sessions were conducted in operant conditioning chambers $(28 \times 23 \times 23 \mathrm{~cm}$; Med Associates). Rats were initially trained to lever press on a continuous reinforcement schedule ( 30 min sessions for $5 \mathrm{~d}$ ) reinforced by high carbohydrate $45 \mathrm{mg}$ pellets (Bio-serv) and were then shifted to the FR5 schedule ( 30 min sessions $5 \mathrm{~d} /$ week) and trained for 5 additional weeks. Rats were then trained on the concurrent FR5/chowfeeding procedure (Salamone et al., 2002; Nunes et al., 2010). Weighed amounts of laboratory chow (5P00 Laboratory Diet; Prolab or RHM 3000; Purina Mills; typically 15-20 g in 3 large pieces) were concurrently available on the floor of the chamber during the FR5 sessions. After the session, rats were immediately removed from the chambers and food intake was determined by weighing the remaining food (including spillage). Rats were trained until they attained stable levels of baseline lever pressing and chow intake (i.e., consistent responding over 1200 lever presses per $30 \mathrm{~min}$; typically 3 weeks), after which time drug testing began. For most baseline days, rats did not receive supplemental feeding; however, over weekends and after drug tests, rats usually received additional chow in the home cage. On baseline and drug treatment days, rats normally consumed all the operant pellets that were delivered from lever pressing during each session. For the food preference study, rats were trained for several weeks in 30 min sessions in which both Bio-serv pellets and laboratory chow were available for consumption. At the end of the session, rats were immediately removed from the chambers and food intake was determined by weighing the remaining food (including spillage).

\section{Surgery}

For intracranial injections, rats received bilateral implantation of guide cannulae made with 25 gauge extra-thin-wall stainless steel tubing (Small Parts), which were implanted $1.0 \mathrm{~mm}$ dorsal to the target site at the following coordinates: accumbens core (AP $+1.6 \mathrm{~mm}$ from the bregma, $\mathrm{ML} \pm 1.4 \mathrm{~mm}$ from the midline, DV $-6.8 \mathrm{~mm}$ from the skull surface; incisor bar $+5.0 \mathrm{~mm}$ above the interaural line); control site $3.0 \mathrm{~mm}$ dorsal to the accumbens core (AP $+1.6 \mathrm{~mm}$ from the bregma, $\mathrm{ML}+1.4$ $\mathrm{mm}$ from the midline, DV $-3.8 \mathrm{~mm}$ from the skull surface; incisor bar $+5.0 \mathrm{~mm}$ above the interaural line). Animals were anesthetized with injection of a solution $(1.0 \mathrm{ml} / \mathrm{kg}$, i.p.) that was prepared by mixing 10.0 $\mathrm{ml}$ of $100.0 \mathrm{mg} / \mathrm{ml}$ ketamine and $0.75 \mathrm{ml}$ of $20.0 \mathrm{mg} / \mathrm{ml}$ xylazine and placed in a stereotaxic device (David Kopf Instruments). For the microdialysis experiment, the tips of the guide cannulae (Bioanalytical Systems) were implanted $2.0 \mathrm{~mm}$ dorsal to the accumbens core (AP +2.8 $\mathrm{mm}, \mathrm{ML}-1.4 \mathrm{~mm}, \mathrm{DV}-5.8 \mathrm{~mm}$ from bregma). All guide cannulae were secured to the skull by stainless steel screws and cranioplastic cement and a stainless steel stylet was inserted through each guide cannula to insure its integrity. After surgery, animals were allowed to recover for a minimum of $7 \mathrm{~d}$ before testing.

\section{Nissl staining for identifying cannula placements}

At the completion of behavioral testing in the intracranial injection and microdialysis experiments, each animal was anesthetized with $\mathrm{CO}_{2}$ and then perfused intracardially with physiological saline followed by a $3.7 \%$ formaldehyde solution. The brains were removed and stored in formaldehyde and then sliced with a cryostat in $50 \mu \mathrm{m}$ sections, which were mounted on glass microscope slides. After mounting, slides were stained with cresyl violet for microscopic observation by an observer who was unaware of the experimental treatment. Any animal with improper cannulae placement or significant damage around the injection site was excluded from the statistical analyses of behavioral data.

\section{DA microdialysis}

On the mornings of sample collection days, dialysis probes (Bioanalytical Systems) were inserted through the microdialysis guide cannulae. Artificial CSF (aCSF; $147.2 \mathrm{~mm} \mathrm{NaCl}, 2.4 \mathrm{~mm} \mathrm{CaCl} 2,4.0 \mathrm{~mm} \mathrm{KCl}$ ) was continuously perfused through the probe at a rate of $2.0 \mu \mathrm{l} / \mathrm{min}$. Neurochemical samples were collected every $30 \mathrm{~min}$ in microcentrifuge tubes that contained $2.0 \mu \mathrm{l}$ of $70 \%$ perchloric acid to prevent oxidation of DA. Twelve samples were collected through the day at an interval of $30 \mathrm{~min}$ for each collection tube. Starting $2 \mathrm{~h}$ after the initial insertion of the probe, the first 5 samples were collected before the intraperitoneal injection of $0.75 \mathrm{mg} / \mathrm{kg}$ tetrabenazine to establish a stable DA level and the last 2 of those baseline samples were used as the statistical baseline. Samples were frozen and analyzed for DA using reverse-phase high-performance liquid chromatography with electrochemical detection (ESA). The electrochemical parameters were as follows: channel $1=-100 \mathrm{mV}$, channel 
$2=+200 \mathrm{mV}$, guard cell $=+350 \mathrm{mV}$. Each liter of mobile phase contains $27.5 \mathrm{~g}$ sodium phosphate monobasic, $7.0 \%$ methanol, $750 \mu \mathrm{l}$ of 0.1 $\mathrm{M}$ EDTA, and $2200 \mu \mathrm{l}$ of $0.4 \mathrm{M}$ sodium octyl sulfate dissolved in deionized ultrapure $\mathrm{H}_{2} \mathrm{O}$ with a final $\mathrm{pH}$ of 4.5 . The flow rate was $1.0 \mathrm{ml} / \mathrm{min}$. DA standards were run before, during, and after the dialysate samples. Probe placements were verified with histological analyses and only probes with placement in the nucleus accumbens core were used for these analyses.

cFos and DARPP-32 immunohistochemical methods

After drug treatments (see below), the animals in Experiments 7-9 were anesthetized with $\mathrm{CO}_{2}$ and transcardially perfused with $0.9 \%$ physiological saline for $5 \mathrm{~min}$, followed by perfusion with $3.7 \%$ formaldehyde for 5 min. Brains were fixed for $24 \mathrm{~h}$ by immersion in $3.7 \%$ formaldehyde and then transferred into a $30 \%$ sucrose solution for $48 \mathrm{~h}$ at $4^{\circ} \mathrm{C}$ before brain sectioning. Free floating coronal sections of brains $(50 \mu \mathrm{m})$ were serially cut using a Cryostat 9 (Thermo Fisher) and rinsed in $0.01 \mathrm{~m}$ phosphate buffer (PBS). To measure the immunoreactivity to phosphorylated DA and c-AMP-regulated phosphoprotein $32 \mathrm{kDa}$ (pDARPP-32), nonspecific binding sites were blocked, and cells were permeabilized in a solution containing $0.1 \%$ Triton X-100 (T.X), 10\% normal donkey serum (NDS) in PBS for $30 \mathrm{~min}$ at room temperature on a rotating platform before primary antibody incubation. pDARPP-32 immunoreactivity was visualized with a polyclonal rabbit antibody for pDARPP-32 phosphorylated at the threonine 34 residue (Thr34, 1:1000; Santa Cruz Biotechnology), or polyclonal rabbit antibody for pDARPP-32 phosphorylated at the threonine 75 residue (Thr75, 1:1000; Santa Cruz Biotechnology). These antibodies were dissolved in solutions that also contained $10 \%$ NDS and $0.1 \%$ T.X in PBS for $48 \mathrm{~h}$ incubation on a rotating shaker at $4^{\circ} \mathrm{C}$. After the primary antibody treatment, the sections were rinsed in PBS (3 times for $5 \mathrm{~min}$ ) and incubated in the secondary antibody, anti-rabbit HRP conjugate envision plus (DAKO) for $2 \mathrm{~h}$ on a rotating shaker at room temperature. Finally, sections were washed and rinsed for 3-5 min in $3,3^{\prime}$ diaminobenzidine chromagen. The sections were then mounted to gelatin-coated slides, air dried, and coverslipped using Cytoseal 60 (Thermo Scientific) as a mounting medium. The tissue was then examined by light microscopy. The processing of the c-Fos tissue was similar to the procedures described for PDARPP-32, with the main difference being the blocking step, which consisted of a solution of $0.3 \% \mathrm{H}_{2} \mathrm{O}_{2}$ and $1 \%$ bovine serum albumin, and the use of a c-Fos specific primary antibody (rabbit polyclonal anti c-Fos, 1:5000; Calbiochem).

\section{Quantification of DARPP-32 and c-Fos-positive cells}

Quantification of the number of cells that express immunoreactivity for c-Fos in nucleus accumbens core and pDARPP-32(Thr34) and pDARPP-32(Thr75) in the nucleus accumbens core and shell was performed by photographing the sections with a $20 \times\left(0.125 \mathrm{~mm}^{2} /\right.$ field $)$ objective (Eclipse E600; Nikon) upright microscope equipped with an Insight Spot digital camera (Diagnostic Instruments). Images of the regions of interest were magnified at $20 \times$ and captured digitally using SPOT software. Cells that were positively labeled for pDARPP32(Thr34), pDARPP-32(Thr75), or c-Fos were quantified with ImageJ software (version 1.42) and a macro written to automate particle counting within the region of interest. The size of the region of interest was $1000 \times 1000 \mu \mathrm{m}$. For each animal, cell counts were at levels that correspond to $0.70-1.70 \mathrm{~mm}$ anterior to bregma (Paxinos and Watson, 1997) bilaterally from at least three sections and counts were averaged across slides and sections.

\section{Immunofluorescence double-labeling studies of DARPP-32,} substance $P$, and enkephalin

Free-floating coronal sections of brains $(50 \mu \mathrm{m})$ were serially cut using a cryostat and rinsed in $0.01 \mathrm{M}$ PBS. To measure the immunoreactivity to pDARPP-32, nonspecific binding sites were blocked and cells were permeabilized in a solution containing $0.1 \%$ T.X and $10 \%$ NDS in PBS for 30 $\mathrm{min}$ at room temperature on a rotating platform before primary antibody incubation. pDARPP-32 immunoreactivity was visualized with a polyclonal rabbit antibody for pDARPP-32(Thr34) (1:500; Santa Cruz Biotechnology) or polyclonal rabbit antibody for pDARPP-32(Thr75) (1:500; Santa Cruz Biotechnology). The different forms of pDARPP-32 were double labeled with primary antibodies for substance P (goat poly- clonal, 1:400; Santa Cruz Biotechnology) or enkephalin (mouse monoclonal, 1:400; Millipore). These antibodies were dissolved in solutions that also contained $10 \%$ NDS and $0.1 \%$ T.X in PBS for a $48 \mathrm{~h}$ incubation on a rotating shaker at $4^{\circ} \mathrm{C}$. After the primary antibody treatment, the sections were rinsed in PBS ( 3 times for $5 \mathrm{~min}$ ) and incubated in the secondary antibody solution containing donkey anti-rabbit Alexa Fluor 488 (1:500; Life Technologies) and donkey anti-goat Alexa Fluor 594 (1:500; Life Technologies) or donkey anti-mouse Alexa Fluor 594 (1:500; Life Technologies). These antibodies were dissolved in solutions that also contained $10 \%$ NDS and $0.1 \%$ T.X in PBS for a $2 \mathrm{~h}$ incubation on a rotating shaker at $22^{\circ} \mathrm{C}$. The sections were then mounted to gelatincoated slides, air dried, and coverslipped using ProLong Gold antifade medium (Life Technologies). Immunofluorescence staining was visualized for high-resolution observation on an Axio Imager M2 upright fluorescent microscope (Carl Zeiss), photographed with a Hamamatsu ORCA-R2 C10600 digital camera, and analyzed with Stereo Investigator software (MicroBrightField).

\section{Behavioral experiments}

Rats were trained on the concurrent FR5/chow-feeding procedure (as described above) before testing began and each experiment used different groups of rats. Experiments 1-4 used a within-groups design, with each rat receiving intraperitoneal drug treatments in their particular experiment in a randomly varied order (one treatment per week, with none of the treatment sequences repeated across different animals in the same experiment). Baseline (i.e., nondrug) sessions were conducted an additional $4 \mathrm{~d}$ per week. Behavioral measures included both the number of lever presses and the amount of freely available laboratory chow that was consumed. The specific treatments and testing times for each experiment are listed below. Experiment 5 involved intracranial injections of tetrabenazine; this experiment was a between-groups design, with each animal receiving only one treatment.

Experiment 1: Effects of systemic administration of the VMAT-2 inhibitor tetrabenazine on the concurrent FR5/chow-feeding procedure. Rats were trained until stable baseline performance was achieved (i.e., lever presses consistently $>1200$ per session). During the experiment, all animals $(n=$ 8) received intraperitoneal injections of the following treatments: $10 \%$ DMSO vehicle and $0.25,0.5,0.75$, and $1.0 \mathrm{mg} / \mathrm{kg}$ tetrabenazine. Injections were given $90 \mathrm{~min}$ before the beginning of the testing session.

Experiment 2: Effects of systemic administration of tetrabenazine on free food intake and preference. Rats were trained the same two foods used in the operant behavior experiments (Bio-serv pellets and laboratory chow) until stable baseline performance was achieved (i.e., food consumption $>10 \mathrm{~g})$. During the experiment, all animals $(n=8)$ received intraperitoneal injections of the following treatments: $10 \%$ DMSO vehicle and 0.25 , $0.5,0.75$, and $1.0 \mathrm{mg} / \mathrm{kg}$ tetrabenazine. Injections were given $90 \mathrm{~min}$ before the beginning of the testing session.

Experiment 3: Effects of systemic administration of tetrabenazine on the concurrent FR5/chow-feeding procedure: reversal with MSX-3. Rats were trained as described above, and then all animals $(n=8)$ received intraperitoneal injections of the following combined treatments: $10 \%$ DMSO vehicle (90 min before testing) plus saline vehicle (20 min before testing), $0.75 \mathrm{mg} / \mathrm{kg}$ tetrabenazine $(90 \mathrm{~min})$ plus saline vehicle $(20$ $\mathrm{min}$ ), $0.75 \mathrm{mg} / \mathrm{kg}$ tetrabenazine (90 min) plus $0.5 \mathrm{mg} / \mathrm{kg} \mathrm{MSX}-3$ (20 $\mathrm{min}), 0.75 \mathrm{mg} / \mathrm{kg}$ tetrabenazine $(90 \mathrm{~min})$ plus $1.0 \mathrm{mg} / \mathrm{kg} \mathrm{MSX}-3$ $(20 \mathrm{~min})$, and $0.75 \mathrm{mg} / \mathrm{kg}$ tetrabenazine $(90 \mathrm{~min})$ plus $2.0 \mathrm{mg} / \mathrm{kg}$ MSX-3 (20 min).

Experiment 4: Effects of systemic administration of tetrabenazine on the concurrent FR5/chow-feeding procedure: reversal with bupropion. Rats were trained as described above, and then all animals $(n=11)$ received intraperitoneal injections of the following combined treatments: $10 \%$ DMSO vehicle ( $90 \mathrm{~min}$ before testing) plus saline vehicle (30 min before testing), $0.75 \mathrm{mg} / \mathrm{kg}$ tetrabenazine ( $90 \mathrm{~min}$ ) plus saline vehicle ( $30 \mathrm{~min}$ ), 0.75 $\mathrm{mg} / \mathrm{kg}$ tetrabenazine $(90 \mathrm{~min})$ plus $5.0 \mathrm{mg} / \mathrm{kg}$ bupropion $(30 \mathrm{~min}), 0.75$ $\mathrm{mg} / \mathrm{kg}$ tetrabenazine $(90 \mathrm{~min}$ ) plus $10.0 \mathrm{mg} / \mathrm{kg}$ bupropion $(30 \mathrm{~min})$, and $0.75 \mathrm{mg} / \mathrm{kg}$ tetrabenazine (90 min) plus $15.0 \mathrm{mg} / \mathrm{kg}$ bupropion (20 min).

Experiment 5: Behavioral effects of tetrabenazine locally administered into the nucleus accumbens core. All animals $(N=24)$ were trained until a stable baseline performance was achieved (i.e., lever presses $>1200$ ). Rats 
were then implanted with bilateral cannulae targeted at the accumbens core $(n=19)$ or a medial neostriatal control site dorsal to the core $(n=$ $5)$. After recovery from surgery and retraining, rats with accumbens core placements received bilateral injections of vehicle $(n=7)$ or $10.0 \mu \mathrm{g}(n=$ 5) or $20.0 \mu \mathrm{g}$ of tetrabenazine $(n=7)$. Animals with dorsal control placements received $20.0 \mu \mathrm{g}$ of tetrabenazine. All injections were given in a total volume of $0.5 \mu \mathrm{l}$ per side and rats were tested $15 \mathrm{~min}$ after drug infusion. This experiment (and Experiment 6) focused on nucleus accumbens core because of previous research showing that the accumbens core is the most effective striatal site at which DA depletion and inactivation produce effects on effort-related choice behavior (Cousins et al., 1993; Sokolowski and Salamone, 1998; Ghods-Sharifi and Floresco, 2010); furthermore, this is a highly effective site for the actions of $D_{2}$ antagonists (Farrar et al., 2010) and adenosine $\mathrm{A}_{2 \mathrm{~A}}$ receptor agonists and antagonists (Font et al., 2008; Mingote et al., 2008; Farrar et al., 2010) on effort-related functions.

\section{Neurochemical experiments}

Neurochemical experiments were conducted to determine the effects of a behaviorally active dose of tetrabenazine $(0.75 \mathrm{mg} / \mathrm{kg}$; see Experiments 3-4 above) on extracellular DA and DA-related markers of signal transduction (c-Fos and pDARPP-32).

Experiment 6: Effect of tetrabenazine on extracellular DA in nucleus accumbens. Rats were implanted with dialysis probes in nucleus accumbens core as described above. On the test day, they received intraperitoneal injections of either vehicle $(n=5)$ or $0.75 \mathrm{mg} / \mathrm{kg}$ tetrabenazine $(n=6)$.

Experiments 7 and 8: Effect of tetrabenazine on $c F$ os and pDARPP-32 expression in nucleus accumbens: reversal with MSX-3. On the test day, untrained rats received intraperitoneal injections of vehicle $(n=16)$, $0.75 \mathrm{mg} / \mathrm{kg}$ tetrabenazine $(n=16)$, or $0.75 \mathrm{mg} / \mathrm{kg}$ tetrabenazine plus 2.0 $\mathrm{mg} / \mathrm{kg}$ MSX-3 $(n=16)$. Of these animals, half in each condition were used for the cFos experiment and were killed $90 \mathrm{~min}$ after injection, and the other half were used for the pDARPP-32 experiment and killed 45 min after injection. Immunocytochemical methods were used to analyze tissue sections as described above.

Experiment 9: Effect of tetrabenazine on pDARPP-32(Thr34) and pDARPP-32(Thr75) expression in substance-P-and enkephalin-positive neurons in nucleus accumbens: immunofluorescence double labeling. Rats received intraperitoneal injections of $0.75 \mathrm{mg} / \mathrm{kg}$ tetrabenazine $(n=6)$. Immunofluorescence double-labeling methods were used to analyze tissue sections as described above to determine the peptides that coexpress with neurons that express pDARPP-32(Thr34) and pDARPP-32(Thr75).

\section{Statistical analyses}

In Experiments 1, 3, and 4, lever presses and gram quantity of chow intake from the $30 \mathrm{~min}$ sessions were analyzed with repeated-measures ANOVA. For the food preference study (Experiment 2), the total quantity of Bio-Serv pellets and chow were analyzed with factorial ANOVA. Experiment 5 was analyzed using between-groups ANOVA. In Experiments 1 and 5, nonorthogonal planned comparisons using the overall error term were used to compare each treatment with the vehicle control condition (Keppel, 1991). For these comparisons, the $\alpha$ level was kept at 0.05 because the number of comparisons was restricted to the number of treatments minus one. In Experiments 3 and 4, each condition that combined tetrabenazine plus MSX-3 or bupropion was compared with the tetrabenazine/vehicle condition using nonorthogonal planned comparisons. Changes in extracellular DA levels in the microdialysis experiment were calculated as the percentage change from baseline, with the mean of the two samples immediately preceding the lever pressing session serving as the $100 \%$ baseline level. A factorial ANOVA with repeated measures on the sample factor was used to test for differences in extracellular levels of DA. The raw DA levels of the baseline samples were analyzed using $t$ test to verify that the baseline DA levels were not different between conditions. For the cFos immunohistochemistry experiment, a betweensubjects ANOVA was used and planned comparisons were used to determine pairwise differences between treatments. For Experiment 8, data for each phosphorylated form of DARPP-32 (i.e., Thr34 and Thr75) were analyzed separately with a brain area (core vs shell) $\times$ drug treat-
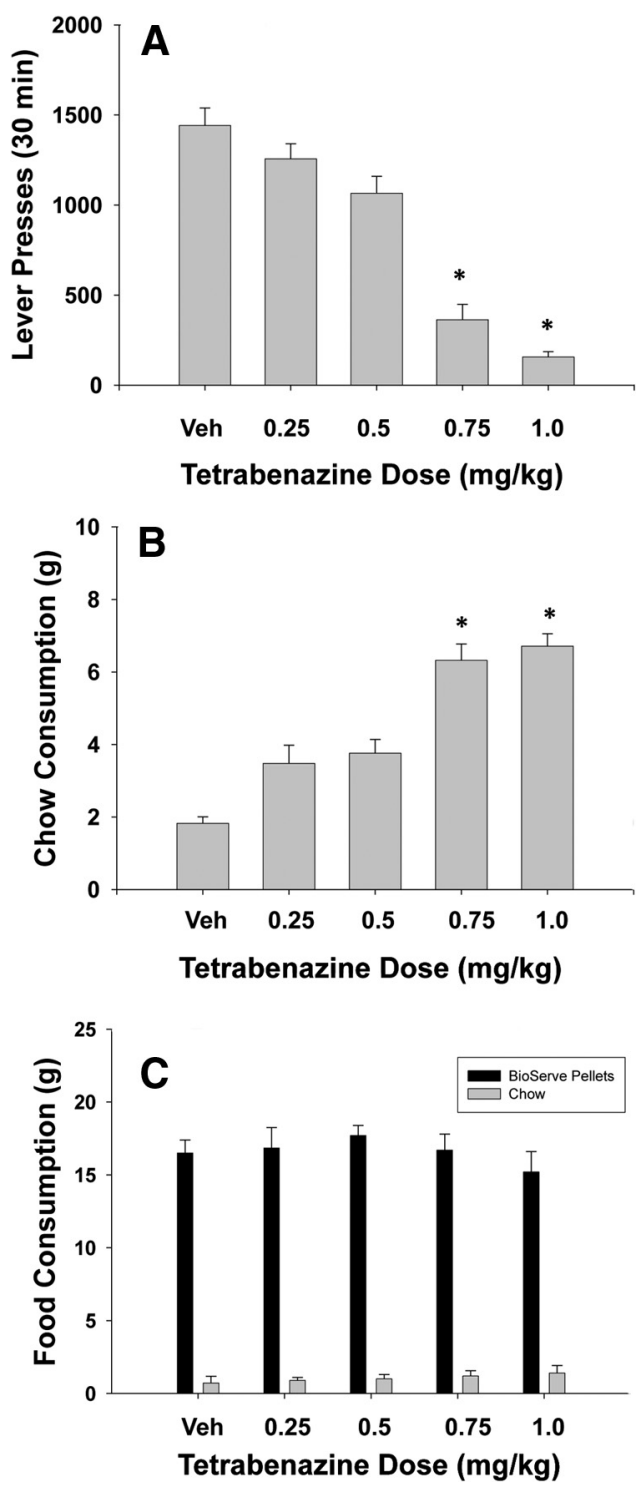

Figure 1. Behavioral effects of tetrabenazine. $\boldsymbol{A}$, Mean ( \pm SEM) number of lever presses after treatment with vehicle and various doses of tetrabenazine $(n=8)$. $\boldsymbol{B}$, Mean ( \pm SEM) intake of laboratory chow (in grams) after treatment with vehicle and various doses of tetrabenazine. ${ }^{*} p<0.05$, different from vehicle, planned comparison. $\boldsymbol{C}$, Mean ( \pm SEM) intake of Bio-serv pellets and laboratory chow (in grams) after treatment with vehicle and various doses of tetrabenazine $(n=8)$.

ment factorial ANOVA, with repeated measures on the brain area factor. When there was a significant area $\times$ treatment interaction, these analyses were followed by separate analyses of each area and post hoc comparisons with the Tukey test $(\alpha=0.05)$.

\section{Results}

Experiment 1: Effects of systemic administration of the VMAT-2 inhibitor tetrabenazine on the concurrent FR5/ chow-feeding procedure

Systemic administration of tetrabenazine significantly decreased lever pressing and produced a concurrent increase in the consumption of the freely available laboratory chow, as shown in Figure 1, $A$ and $B$. ANOVA revealed a significant effect of dose on lever pressing $\left(F_{(4,28)}=45.9, p<0.001\right)$. There was also an overall significant effect of drug treatment on chow intake $\left(F_{(4,28)}=33.8, p<0.001\right)$. Planned comparisons were performed and showed that the two highest doses of tetrabenazine significantly decreased lever pressing 
and increased the consumption of the freely available laboratory chow relative to control $(p<0.05)$.

Experiment 2: Effects of systemic administration of tetrabenazine on free food intake and preference

The results of Experiment 2 are shown in Figure $1 C$. There was a significant difference between food type consumed, with rats preferring the Bio-serv pellets over the standard laboratory chow $\left(F_{(1,14)}=\right.$ $661 ; p<0.001)$. However, there was no significant effect of drug treatment on food intake $(p>0.05)$ and no significant drug treatment $\times$ food type interaction $(p>0.05)$.

Experiments 3 and 4: Effects of systemic administration of the tetrabenazine on the concurrent FR5/chow-feeding procedure: reversal with MSX-3 and bupropion

The results of Experiment 3 are shown in Figure 2, $A$ and $B$. MSX-3 was able to attenuate the behavioral effects of tetrabenazine. There was an overall significant effect of drug treatment on lever pressing $\left(F_{(4,28)}=26.8, p<0.001\right)$. There was also an overall significant effect of drug treatment on chow intake $\left(F_{(4,28)}=40.5, p<\right.$ 0.001). Planned comparisons were performed and showed that tetrabenazine suppressed lever pressing and increased chow intake and that all doses of MSX-3 were able to attenuate the effects of tetrabenazine both on lever pressing and consumption of the freely available laboratory chow relative to the tetrabenazine alone condition $(p<0.05)$.

As shown in Figure 2, $C$ and $D$, the antidepressant bupropion was able to attenuate the behavioral effects of tetrabenazine. There was an overall significant effect of drug treatment on lever pressing $\left(F_{(4,40)}=19.4, p<0.001\right)$ and also an overall significant effect of drug treatment on chow intake $\left(F_{(4,40)}=46.3, p<0.001\right)$. Planned comparisons showed that, as in the previous two experiments, $0.75 \mathrm{mg} / \mathrm{kg}$ tetrabenazine decreased lever pressing and increased chow intake. In addition, the two highest doses of bupropion significantly increased lever pressing and also decreased the consumption of the freely available laboratory chow relative to the tetrabenazine condition $(p<0.05)$.

Experiment 5: Effects of tetrabenazine locally administered into the nucleus accumbens core on the concurrent FR5/ chow-feeding procedure

Results of Experiment 5 are shown in Figure 3. There was an overall significant effect of drug treatment on lever pressing $\left(F_{(3,23)}=16.9, p<0.001\right)$ and also on chow intake $\left(F_{(3,23)}=22.2\right.$, $p<0.001$. Planned comparisons showed that accumbens core injections of the highest dose of tetrabenazine produced a significant effect on lever pressing and chow consumption compared with vehicle $(p<0.05)$. Injection of $20.0 \mu \mathrm{g}$ of tetrabenazine into
Tetrabenazine Reversal with MSX-3

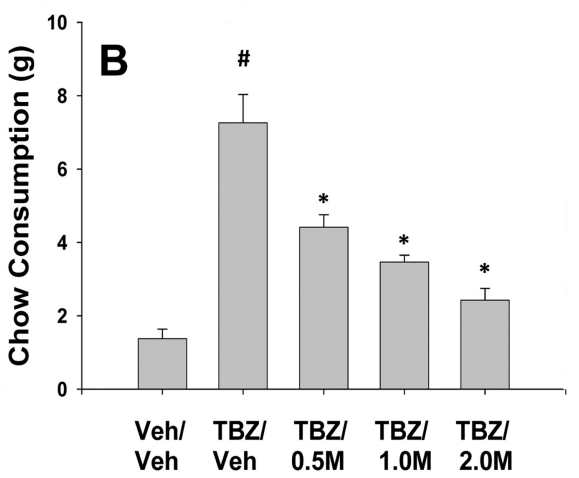

Drug Treatment

\section{Tetrabenazine Reversal with Bupropion}

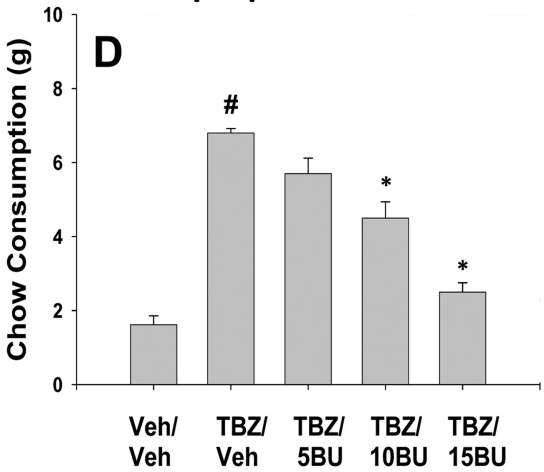

Drug Treatment

Figure 2. The effects of the adenosine $A_{2 A}$ antagonist MSX-3 and the antidepressant bupropion on tetrabenazine-induced received intraperitoneal injections of vehicle plus vehicle (Veh/Veh), $0.75 \mathrm{mg} / \mathrm{kg}$ tetrabenazine plus vehicle (TBZ/Veh), or tetra作 $0.25,0.5,1.0$, or $2.0 \mathrm{mg} / \mathrm{kg}$ doses of MSX-3 (M). $\boldsymbol{A}$, Mean ( \pm SEM) number of lever presses (FR5 schedule) during the session. $\boldsymbol{D}$, Mean ( \pm SEM) gram quantity of chow intake. \#p $<0.05$, tetrabenazine plus vehicle significantly differed from vehicle/vehicle; ${ }^{*} p<0.05$, significantly different from tetrabenazine plus vehicle.

the neostriatal control site dorsal to the accumbens core did not alter lever pressing or chow intake compared with vehicle, but this group did differ on both measures from the rats that received the same dose into the nucleus accumbens ( $p<0.05$, Tukey test).

Experiment 6: Effect of tetrabenazine on extracellular DA in nucleus accumbens

Figure $4 \mathrm{~A}$ summarizes the results of the microdialysis experiment. The vehicle $(n=5)$ and $0.75 \mathrm{mg} / \mathrm{kg}$ tetrabenazine $(n=6)$ groups did not differ in terms of baseline levels of extracellular DA (mean + SEM DA expressed as picograms/sample; vehicle: $27.5 \pm 8.1$; tetrabenazine: $21.6 \pm 4.5 ; t=0.55, \mathrm{df}=9, p>0.5$, NS). Factorial ANOVA across all 9 samples (Fig. $4 A$ ) demonstrated that there was a significant effect of drug treatment $\left(F_{(1,9)}=8.1\right.$, $p<0.05)$, a significant difference across samples $\left(F_{(8,72)}=3.53\right.$, $p<0.05)$, and a significant treatment $\times$ sample interaction $\left(F_{(8,72)}=2.3, p<0.05\right)$. Separate analyses of each treatment group showed that there was no significant change over samples in the vehicle group $\left(F_{(8,32)}=0.192, p>0.9\right.$, NS), but there was a significant change in DA levels across samples for the tetrabenazine group $\left(F_{(8,40)}=5.81, p<0.001\right)$. Planned comparisons showed that animals injected with $0.75 \mathrm{mg} / \mathrm{kg}$ tetrabenazine had 
A

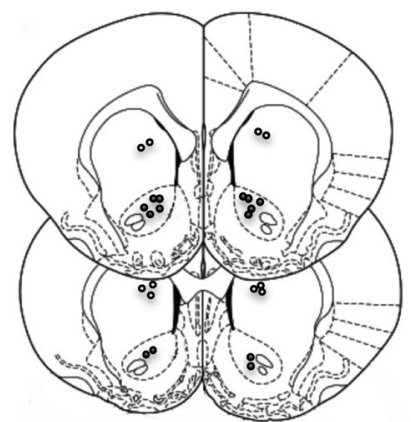

Intra-NAc TBZ Placements
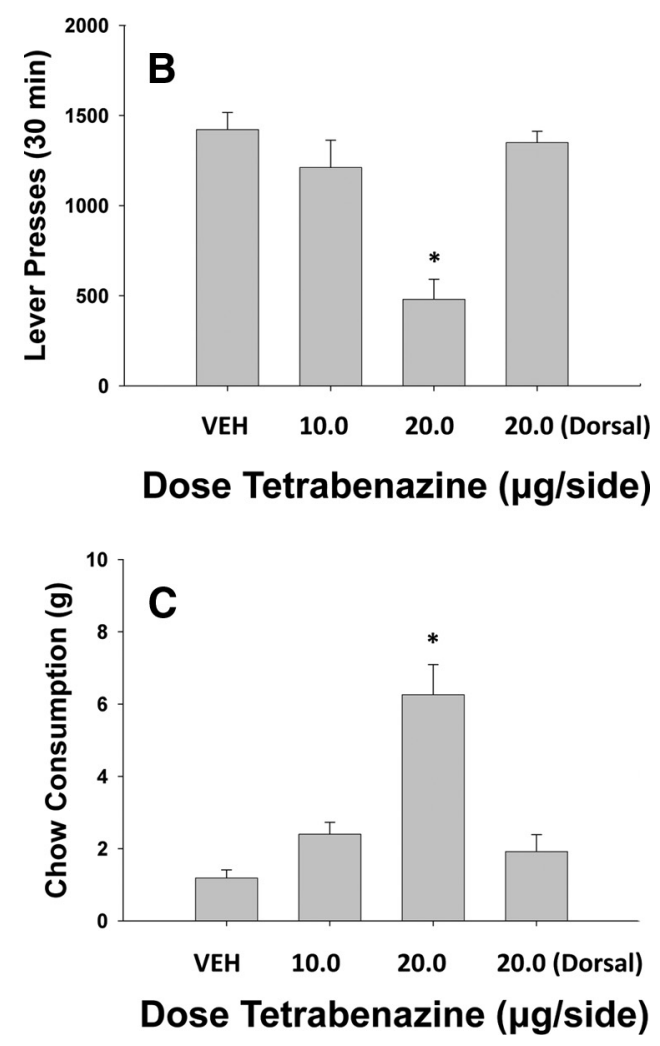

Figure 3. Intracranial administration of tetrabenazine. $A$, Placements of cannulae in nucleus accumbens core (filled circles) and the dorsal control site (open circles) in rats that received the $20.0 \mu \mathrm{g}$ dose of tetrabenazine. $\boldsymbol{B}$, Mean ( \pm SEM) number of lever presses after treatment with either vehicle $(n=7), 10.0 \mu \mathrm{g}(n=5)$, or $20.0 \mu \mathrm{g}(n=7)$ per side of tetrabenazine injected into nucleus accumbens core or $20.0 \mu \mathrm{g}$ per side injected into the dorsal control site $(n=5)$. C, Mean ( \pm SEM) intake of laboratory chow (in grams) after treatment with vehicle, $10.0 \mu \mathrm{g}$ or $20.0 \mu \mathrm{g}$ per side of tetrabenazine injected into nucleus accumbens core, or $20.0 \mu \mathrm{g}$ per side injected into the dorsal control site. ${ }^{*} p<0.05$, different from vehicle, planned comparison.

significantly lower levels of extracellular DA in samples D4-D7 relative to the last baseline sample $(p<0.05)$.

Experiments 7-9: Tetrabenazine affects the DA-related signal transduction markers cFos and DARPP-32

The results of immunocytochemistry experiments are shown in Figure $4, B-D$, and Figure 5 . There was an overall effect of drug treatment on the number of cFos positive cell in nucleus accumbens core $\left(F_{(2,23)}=73.0, p<0.001\right.$; Fig. $\left.4 B\right)$. Planned comparisons showed that tetrabenazine increased cFos-positive cells counts relative to vehicle alone $(p<0.05)$ and that the combination of tetrabenazine plus MSX-3 differed significantly from tetrabenazine plus vehicle $(p<0.05)$. In Experiment 8 , analyses of pDARPP-32(Thr34) immunoreactivity (Fig. $4 C$ ) showed that there was no overall difference between core and shell $\left(F_{(1,21)}=\right.$ 0.5 , NS), but there was an overall effect of drug treatment on the number of pDARPP-32(Thr34)-positive cells $\left(F_{(2,21)}=87.72\right.$, $p<0.05)$ and a significant brain area $\times$ drug treatment interaction $\left(F_{(2,21)}=6.18, p<0.05\right)$. Separate ANOVAs of core and shell revealed that the drug treatment effects were significant in both areas $(p<0.05)$ and planned comparisons revealed that tetrabenazine produced a significant increase in PDARPP-32(Thr34) expression $(p<0.05)$ in both areas, which was suppressed by coadministration of MSX-3 $(p<0.05)$. However, the source of the interaction was that MSX-3 produced a greater suppression of tetrabenazine-induced expression of pDARPP-32(Thr34) in the core relative to shell $(p<0.05)$. There was also an overall effect of drug treatment on the number of pDARPP-32(Thr75)positive cells $\left(F_{(2,21)}=72.5, p<0.05\right.$; Fig. $\left.4 D\right)$, but no significant core versus shell difference $\left(F_{(1,21)}=1.5, \mathrm{NS}\right)$ and no brain area $\times$ treatment interaction $\left(F_{(2,21)}=1.8, \mathrm{NS}\right)$. Collapsed across both regions, tetrabenazine produced an overall increase in pDARPP32(Thr75) expression $(p<0.05)$, but MSX-3 failed to suppress the tetrabenazine-induced increase in pDARPP-32(Thr75)positive cells. Figure 5 shows the results of the immunofluorescence double-labeling study. In animals treated with $0.75 \mathrm{mg} / \mathrm{kg}$ tetrabenazine, pDARPP-32(Thr34) was coexpressed with enkephalin, but not substance $\mathrm{P}$, whereas pDARPP-32(Thr75) was coexpressed with substance $P$, but not enkephalin. Together with the results of the single-labeling experiment (Fig. $4 B, C$ ), this pattern of results is consistent with a reduction of $D_{1}$ and $D_{2}$ receptor signaling induced by tetrabenazine.

\section{Discussion}

These experiments assessed the effort-related motivational effects of the VMAT-2 inhibitor tetrabenazine. Animals show robust activation in the initiation and maintenance of motivated behavior (Salamone and Correa, 2002, 2012; Berridge and Robinson, 2003; Robbins and Everitt, 2007; Nicola, 2010; McGinty et al., 2013) and demonstrate substantial and persistent work output in their instrumental actions. Moreover, they frequently make effort-related decisions, allocating behavioral resources in relation to the motivational value of stimuli and the effort required to obtain them (Salamone and Correa, 2012). The present experiments used the FR5/chow-feeding task as a measure of effort-related choice behavior (Salamone et al., 1991, 1997; Nunes et al., 2010). This task is sensitive to the effects of $D_{1}$ or $D_{2}$ antagonism and accumbens DA depletions (Salamone et al., 1991, 2002; Cousins et al., 1994; Nowend et al., 2001; Sink et al., 2008; Farrar et al., 2010). Furthermore, the effects of interference with DA transmission on this task are not due to changes in appetite, food intake, or preference (Salamone et al., 1991; Koch et al., 2000) and do not resemble the effects of reinforcer devaluation by prefeeding (Salamone et al., 1991) or appetite suppressant drugs (Cousins et al., 1994; Salamone et al., 2002; Sink et al., 2008). As shown above, tetrabenazine shifted choice behavior, decreasing lever pressing but increasing consumption of the concurrently available chow. In a parallel experiment, the same doses of tetrabenazine had no effect on food intake or preference for high carbohydrate pellets over chow. Therefore, tetrabenazineinduced shifts in effort-related choice were not due to changes in primary food motivation, the unconditioned reinforcing properties of food, or food preference. Although tetrabenazine exerted a selective effect on the tendency to work for food by lever pressing, tetrabenazine-treated rats remained directed toward food acquisition and consumption and selected an alternative path to obtain food (i.e., approach/consumption of the concurrently available 
chow). This conclusion is consistent with preliminary studies demonstrating that tetrabenazine also reduced selection of the high effort/high reward option in rats tested on a T-maze barrier choice task (Yohn et al., 2012) and a progressive ratio/chow feeding choice procedure (Salamone et al., 2012). Injections of tetrabenazine into accumbens core also reduced FR5 lever pressing and increased chow intake (Fig. 3), whereas injections into a medial neostriatal control site dorsal to accumbens were ineffective. This is consistent with previous studies linking effort-related choice behavior to accumbens DA (Salamone et al., 1991; Cousins et al., 1993; Nowend et al., 2001; Farrar et al., 2010; Mai et al., 2012; Trifilieff et al., 2013).

Tests of effort-related choice behavior may have utility as preclinical models of motivational symptoms such as psychomotor retardation, anergia, and fatigue, which are seen in depression and other disorders (Salamone et al., 2006, 2007, 2010; Salamone and Correa, 2012). This idea is consistent with human studies of effort-related decision making showing that decreased selection of high effort/high reward options is seen in patients with major depression (Treadway et al., 2012b) and also in schizophrenics with a preponderance of negative symptoms (Gold et al., 2013). Because tetrabenazine produces depressive symptoms including psychomotor slowing and fatigue in human patients (Frank, 2009; Guay, 2010; Chen et al., 2012), the adenosine $\mathrm{A}_{2 \mathrm{~A}}$ antagonist MSX-3 and the catecholamine uptake blocker bupropion were assessed for their ability to reverse the behavioral effects of tetrabenazine. Adenosine $\mathrm{A}_{2 \mathrm{~A}}$ antagonists produce behavioral effects in animals that are consistent with antidepressant actions (Hodgson et al., 2009; Hanff et al., 2010), and bupropion (Wellbutrin) is a widely used antidepressant drug (Milea et al., 2010) that can produce antidepressant-like effects in rodent tasks such as the forced swim and tail suspension tests (Bourin et al., 2005; Kitamura et al., 2010). MSX-3 fully reversed the effects of tetrabenazine on FR5/chow-feeding choice performance, which is consistent with research demonstrating that adenosine $\mathrm{A}_{2 \mathrm{~A}}$ antagonists reverse the effects of $\mathrm{DA} \mathrm{D}_{2}$ family antagonists on effort-related choice behavior (Farrar et al., 2007; Mott et al., 2009; Salamone et al., 2009; Worden et al., 2009; Nunes et al., 2010; Santerre et al., 2012). Bupropion, a catecholamine uptake blocker that elevates extracellular DA and norepinephrine (Hudson et al., 2012), also reversed the effort-related effects of tetrabenazine. It is not clear which catecholamine mediates this action, but there is little evidence implicating norepinephrine in effort-related choice and considerable evidence supporting a role for DA (Salamone et al., 2007). Nevertheless, in view of the

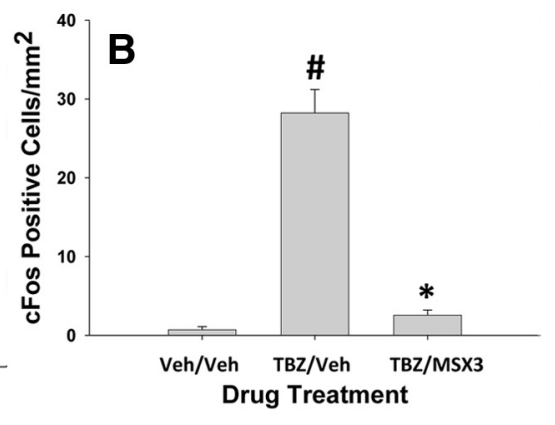

pDARPP-32 (Thr34)

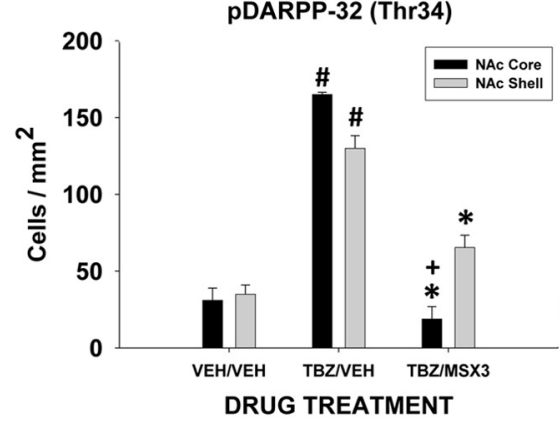

pDARPP-32 (Thr75)

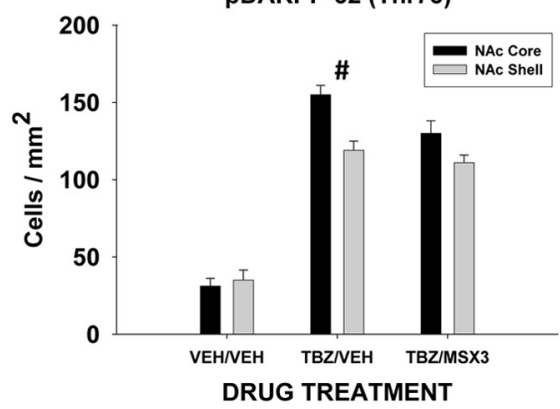

Figure 4. Neurochemical effects of tetrabenazine. $A$, Microdialysis data showing the effect of $0.75 \mathrm{mg} / \mathrm{kg}$ tetrabenaine on mean ( \pm SEM) extracellular DA (expressed as percentage of baseline) in nucleus accumbens core. Samples ( $30 \mathrm{~min}$ ) were collected during the baseline period (BL1 and BL2) and for the 7 samples after the injection of either tetrabenazine $(n=6)$ or vehicle $(n=5)$ (D1-D7). ${ }^{*} p<0.05$, different from last baseline sample in the tetrabenazine group. $\boldsymbol{B}$, Expression of c-Fos immunoreactivity in nucleus accumbens core. Mean ( \pm SEM) number of c-Fos-positive cells in the accumbens and core after injection of vehicle plus vehicle (Veh/Veh; $n=8$ ), $0.75 \mathrm{mg} / \mathrm{kg}$ tetrabenazine plus vehicle (TBZ/Veh; $n=8$ ), or tetrabenazine plus the $2.0 \mathrm{mg} / \mathrm{kg}$ dose of MSX-3 $(n=8)$. $\# p<0.05$, tetrabenazine plus vehicle significantly differed from vehicle/vehicle; ${ }^{*} p<0.05$, significantly different from tetrabenazine plus vehicle. $C$, Expression of pDARPP-32(Thr34) immunoreactivity in nucleus accumbens core and shell after

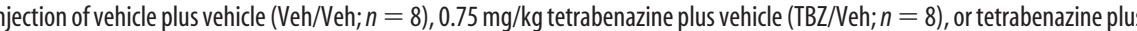
the $2.0 \mathrm{mg} / \mathrm{kg}$ dose of MSX-3 $(n=8)$. Left, Photomicrographs of individual animals. Right, Mean \pm SEM number of pDARPP32(Thr34)-positive cells. $\# p<0.05$, tetrabenazine plus vehicle significantly differed from vehicle/vehicle; ${ }^{*} p<0.05$, significantly sion of pDARPP-32(Thr75) immunoreactivity in nucleus accumbens core and shell after injection of vehicle plus vehicle (Veh/Veh; $n=8), 0.75 \mathrm{mg} / \mathrm{kg}$ tetrabenazine plus vehicle (TBZ/Veh; $n=8$ ), or tetrabenazine plus the $2.0 \mathrm{mg} / \mathrm{kg}$ dose of MSX-3 $(n=8)$. Left, Photomicrographs of individual animals. Right, Mean \pm SEM number of pDARPP-32(Thr75) positive cells. \#Tetrabenazine plus vehicle significantly differed from vehicle/vehicle across both core and shell.

known antidepressant actions of bupropion in humans, these results validate the hypothesis that tests of effort-related choice behavior can be used to assess some of the motivational effects of antidepressant drugs. Furthermore, these results are consistent with clinical data indicating that bupropion is relatively effective for treating psychomotor retardation and fatigue symptoms of depression (Fabre et al., 1983; Pae et al., 2007) and can be more effective than other antidepressants, including 5-HT uptake blockers, for treating motivational dysfunction in depressed patients (Papakostas et al., 2006). 


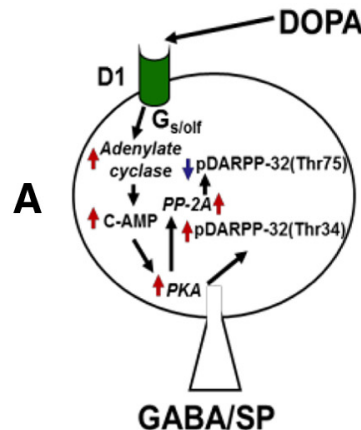

GABA/SP

Co-localization:

pDARPP-32 Thr75/Substance $P$

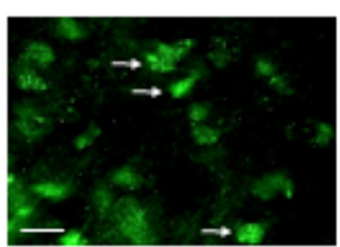

B
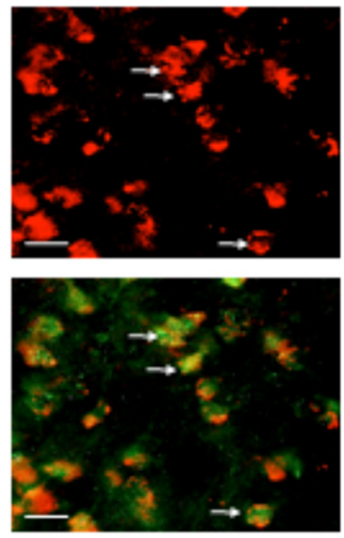

Merged

Thr75
pDARPP-32

Substance P

Co-localization Absent: pDARPP-32 Thr34/Substance P

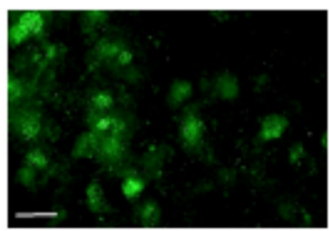

PDARPP-32

Thr34
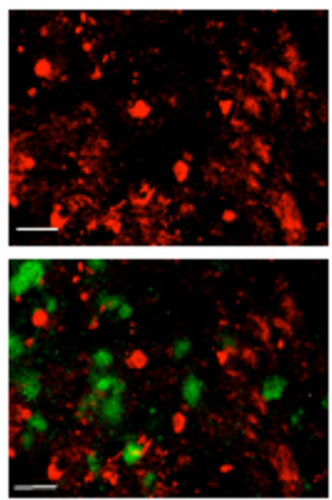

Substance P

Merged
TBZ

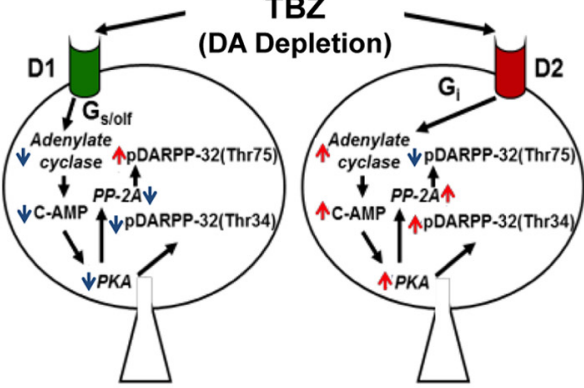

GABA/SP

Co-localization: pDARPP-32 Thr34/Enkephalin

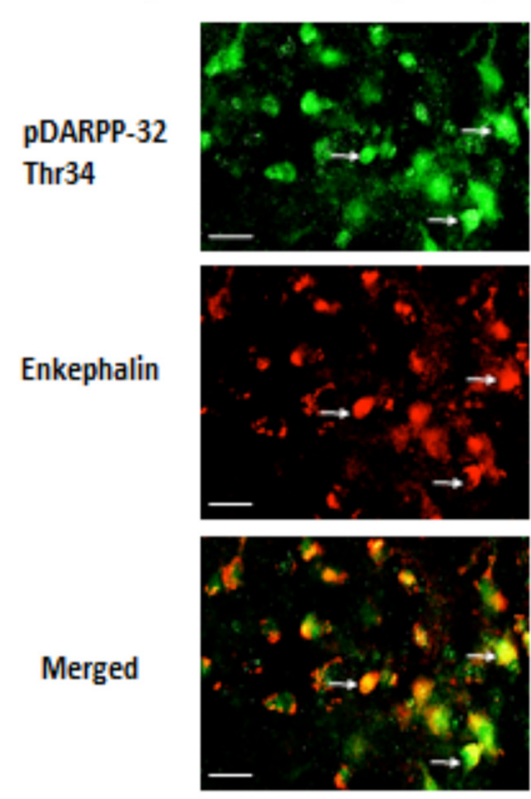

Co-localization Absent:

pDARPP-32 Thr75/Enkephalin

pDARPP-32

Thr75

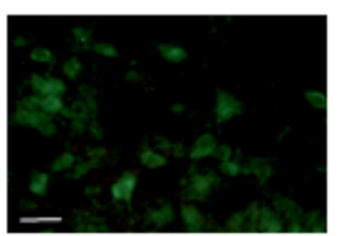

Enkephalin

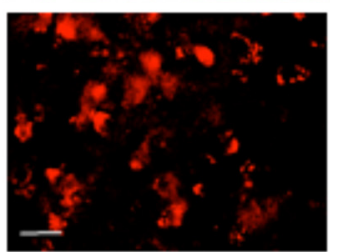

Merged

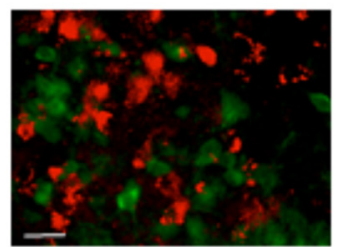

Figure 5. A, Left, Diagram showing effect of DA on DARPP-32 phophorylation (for details, see Svenningsson et al., 2004; Bateup et al., 2008; Yger and Girault, 2011). D 1 receptor stimulation increases c-AMP production and protein kinase A (PKA) activity, which phosphorylates DARPP-32 to yield pDARPP-32(Thr34). $D_{2}$ receptor stimulation decreases c-AMP production and protein kinase A activity, which decreases the dephosphorylation of pDARPP-32(Thr75) by protein phosphatase 2A (PP-2A) and therefore increases pDARPP-32(Thr75) expression. Right, Tetrabenazine, which depletes DA, was hypothesized to have the opposite effect of DA, increasing pDARPP-32(Thr75) in substance-P-positive neurons and pDARPP-32(Thr34) in (Figure legend continues.) 
Tetrabenazine substantially reduced extracellular DA in accumbens core as measured by microdialysis and also affected DA-related signal transduction in a manner consistent with reduced accumbens $D_{1}$ and $D_{2}$ receptor transmission. Tetrabenazine increased cFos immunoreactivity in accumbens core and shell, which is consistent with a reduction in $\mathrm{D}_{2}$ transmission (Robertson et al., 1992; Santerre et al., 2012). Furthermore, immunocytochemistry of different forms of phosphorylated DARPP-32 indicated that $0.75 \mathrm{mg} / \mathrm{kg}$ tetrabenazine significantly increased accumbal expression of both pDARPP-32(Thr34) and pDARPP-32(Thr75). Previous results suggest that tetrabenazineinduced increases in pDARPP-32(Thr75) would reflect reduced transmission at $\mathrm{DA}_{1}$ family receptors, whereas the increase in pDARPP-32(Thr34) would mark reduced transmission at $\mathrm{DA} \mathrm{D}_{2}$ family receptors (Svenningsson et al., 2004; Bateup et al., 2008; Yger and Girault, 2011; Santerre et al., 2012). These DA receptors are largely localized on separate populations of medium spiny neurons, so immunofluorescence double-labeling studies for both forms of pDARPP-32 were conducted to determine whether there was coexpression with either substance $\mathrm{P}$ (marking $\mathrm{D}_{1^{-}}$receptor-containing cells) or enkephalin (marking $\mathrm{D}_{2}$-receptorcontaining cells; Segovia et al., 2012). These double-labeling studies confirmed that, in tetrabenazine-treated rats, pDARPP32(Thr75) expression was in substance-P-positive cells, whereas pDARPP-32(Thr34) expression was in enkephalin-positive cells. Interestingly, MSX-3 attenuated the effects of tetrabenazine on pDARPP-32(Thr34) expression, but not pDARPP-32(Thr75) expression. This is consistent with studies showing that adenosine $A_{2 A}$ receptors are colocalized with $D_{2}$ receptors on enkephalinpositive neurons, but not with $\mathrm{D}_{1}$ receptors on substance-Ppositive neurons (Svenningsson et al., 1999), and that $A_{2 A}$ and $D_{2}$ receptors can form heteromers and interact via convergence onto c-AMP signal transduction cascades (Ferré et al., 2008). The suppression of tetrabenazine-induced increases in pDARPP32(Thr34) expression by MSX-3 was greater in the core versus the shell, which may be due to a lower level of adenosine $\mathrm{A}_{2 \mathrm{~A}}$ receptor expression in the shell (Rosin et al., 1998; Ishiwari et al., 2007).

By inhibiting VMAT-2, tetrabenazine affects monoamine storage, but studies indicate that the greatest effects are on striatal DA. A study of postmortem tissue of humans receiving clinical doses of tetrabenazine reported that the only statistically significant depletions were DA in the caudate, norepinephrine in the amygdala, and norepinephrine and DA in the hippocampus (Guay, 2010). Pettibone et al. (1984) showed that $1.0 \mathrm{mg} / \mathrm{kg}$ tetrabenazine reduced striatal DA in rats by $\sim 75 \%$ while reducing 5 -HT and norepinephrine by $\sim 15-30 \%$, and observed that a dose of $10.0 \mathrm{mg} / \mathrm{kg}$ tetrabenazine was needed to reduce $5-\mathrm{HT}$ as much as $1.0 \mathrm{mg} / \mathrm{kg}$ depleted striatal DA. Similar results were shown by Tanra et al. (1995), who reported that $1.0 \mathrm{mg} / \mathrm{kg}$ tetrabenazine reduced striatal DA in rats by $57 \%$, whereas with $5-\mathrm{HT}$, there were no significant reductions in frontal cortex, striatum, or hippocampus and only a $20 \%$ reduction in hypothalamus. No studies specifically demonstrate a role for norepinephrine in

(Figure legend continued.) encephalin-positive neurons. $\boldsymbol{B}, \boldsymbol{C}$, Immunofluorescence double labeling of different forms of phosphorylated DARPP-32. $\boldsymbol{B}$, pDARPP-32(Thr34) immunofluorescence is localized in encephalin-positive neurons (yellow/orange areas of cells in merged photo), whereas pDARPP-32(Thr75) immunofluorescence activity is colocalized with substance $P$ (yellow/orange areas of cells in merged photo). C, pDARPP-32(Thr34) is not present in substance-P-positive neurons (separate green and red cells in merged photo) and pDARPP$32(T h r 75)$ is not colocalized with enkephalin immunofluorescence activity (separate green and red cells in merged photo). effort-related decision making, but one report indicates that depletion of 5-HT does not affect performance in rats responding on the T-maze barrier choice task (Denk et al., 2005). Together with the present results, these studies support the hypothesis that the effects of tetrabenazine on effort-related choice are largely due to actions on DA.

In summary, tetrabenazine alters effort-related choice behavior, reducing food-reinforced lever pressing and biasing animals toward selection of the freely available chow at doses that did not affect food preference or consumption. The ability of tetrabenazine to affect effort-based decision making is consistent with research showing that other manipulations associated with depression, including stress (Shafiei et al., 2012) and administration of proinflammatory cytokines (Nunes et al., 2003b), can alter effort-based choice. The behavioral effects of tetrabenazine were attenuated by coadministration of an adenosine $\mathrm{A}_{2 \mathrm{~A}}$ antagonist and the antidepressant bupropion. Future research should study the effort-related effects of additional antidepressant drugs with different pharmacological profiles. Consistent with studies demonstrating DAergic involvement in effort-related processes and with research implicating DA in motivational symptoms of depression (Rampello et al., 1991; Brown and Gershon, 1993; Treadway and Zald, 2011; Argyropoulos and Nutt, 2013; Soskin et al., 2013), tetrabenazine reduced extracellular DA and altered DARPP-32 signaling in both substance-P- and enkephalincontaining accumbens neurons. This research could have implications for understanding the neural circuits underlying effort-related motivational dysfunctions in depression, schizophrenia, and other disorders.

\section{References}

Argyropoulos SV, Nutt DJ (2013) Anhedonia revisited: Is there a role for dopamine-targeting drugs for depression? J Psychopharmacol 27:869877. CrossRef Medline

Bardgett ME, Depenbrock M, Downs N, Points M, Green L (2009) Dopamine modulates effort-based decision making in rats. Behav Neurosci 123:242-251. CrossRef Medline

Bateup HS, Svenningsson P, Kuroiwa M, Gong S, Nishi A, Heintz N, Greengard P (2008) Cell type-specific regulation of DARPP-32 phosphorylation by psychohostimulant and anti-psychotic drugs. Nat Neurosci 11: 932-939. CrossRef Medline

Bella R, Pennisi G, Cantone M, Palermo F, Pennisi M, Lanza G, Zappia M, PaolucciS (2010) Clinical presentation and outcome of geriatric depression in subcortical ischemic vascular disease. Gerontology 56:298-302. CrossRef Medline

Berridge KC, Robinson TE (2003) Parsing reward. Trends Neurosci 26:507513. CrossRef Medline

Bourin M, Chenu F, Ripoll N, David DJ (2005) A proposal of decision tree to screen putative antidepressants using forced swim and tail suspension tests. Behav Brain Res 7; 164:266-269. CrossRef Medline

Brown AS, Gershon S (1993) Dopamine and depression. J Neural Transm Gen Sect 91:75-109. CrossRef Medline

Cagniard B, Balsam PD, Brunner D, Zhuang X (2006) Mice with chronically elevated dopamine exhibit enhanced motivation, but not learning, for a food reward. Neuropsychopharmacology 31:1362-1370. CrossRef Medline

Chen JJ, Ondo WG, Dashtipour K, Swope DM (2012) Tetrabenazine for the treatment of hyperkinetic movement disorders: a review of the literature. Clin Ther 34:1487-1504. CrossRef Medline

Cousins MS, Sokolowski JD, Salamone JD (1993) Different effects of nucleus accumbens and ventrolateral striatal (DA) depletions on instrumental response selection in the rat. Pharmacol Biochem Behav 46:943-951. CrossRef Medline

Cousins MS, Wei W, Salamone JD (1994) Pharmacological characterization of performance on a concurrent lever pressing/feeding choice procedure: effects of dopamine antagonists, cholinomimetic, sedative and stimulant drugs. Psychopharmacology (Berl) 116:529-537. CrossRef Medline

Croxson PL, Walton ME, O’Reilly JX, Behrens TE, Rushworth MF (2009) 
Effort-based cost-benefit valuation and the human brain. J Neurosci 29: 4531-4541. CrossRef Medline

Denk F, Walton ME, Jennings KA, Sharp T, Rushworth MF, Bannerman DM (2005) Differential involvement of serotonin and dopamine systems in costbenefit decisions about delay or effort. Psychopharmacology 179: 587-596.

Fabre LF, Brodie HK, Garver D, Zung WW (1983) A multicenter evaluation of bupropion versus placebo in hospitalized depressed patients. J Clin Psychiatry 44:88-94. Medline

Farrar AM, Pereira M, Velasco F, Hockemeyer J, Müller CE, Salamone JD (2007) Adenosine $\mathrm{A}(2 \mathrm{~A})$ receptor antagonism reverses the effects of (DA) receptor antagonism on instrumental output and effort-related choice in the rat: implications for studies of psychomotor slowing. Psychopharmacology 191:579-586. CrossRef Medline

Farrar AM, Segovia KN, Randall PA, Nunes EJ, Collins LE, Stopper CM, Port RG, Hockemeyer J, Müller CE, Correa M, Salamone JD (2010) Nucleus accumbens and effort-related functions: behavioral and neural markers of the interactions between adenosine $\mathrm{A}_{2 \mathrm{~A}}$ and (DA) $\mathrm{D}_{2}$ receptors. Neuroscience 166:1056-1067. CrossRef Medline

Ferré S, Quiroz C, Woods AS, Cunha R, Popoli P, Ciruela F, Lluis C, Franco R, Azdad K, Schiffmann SN (2008) An update on adenosine A2Adopamine D2 receptor interactions: implications for the function of $G$ protein-coupled receptors. Curr Pharm Des 14:1468-1474.

Floresco SB, Ghods-Sharifi S (2007) Amygdala-prefrontal contrical circuitry regulates effort-based decision making. Cereb Cortex 17:251-260. CrossRef Medline

Floresco SB, Tse MT, Ghods-Sharifi S (2008) Dopaminergic and glutamatergic regulation of effort- and delay-based decision making. Neuropsychopharmacology 33:1966-1979. CrossRef Medline

Font L, Mingote S, Farrar AM, Pereira M, Worden L, Stopper C, Port RG, Salamone JD (2008) Intra-accumbens injections of the adenosine A(2A) agonist CGS 21680 affect effort-related choice behavior in rats. Psychopharmacology 199:515-526.

Frank S (2009) Tetrabenazine as anti-chorea therapy in Huntington Disease: an open-label continuation study. Huntington Study Group/ TETRA-HD Investigators. BMC Neurol 9:62. CrossRef Medline

Frank S (2010) Tetrabenazine: the first approved drug for the treatment of chorea in US patients with Huntington's disease. Neuropsychiatr Dis Treat 5:657-665. CrossRef Medline

Ghods-Sharifi S, Floresco SB (2010) Differential effects on effort discounting induced by inactivations of the nucleus accumbens core or shell. Behav Neurosci 124:179-191. CrossRef Medline

Gold JM, Strauss GP, Waltz JA, Robinson BM, Brown JK, Frank MJ (2013) Negative symptoms of schizophrenia are associated with abnormal effortcost computations. Biol Psychiatry 74:130-136.

Guay DR (2010) Tetrabenazine, a monoamine-depleting drug used in the treatment of hyperkinectic movement disorders. Am J Geriatr Pharmacother 8:331-373. CrossRef Medline

Hanff TC, Furst SJ, Minor TR (2010) Biochemical and anatomical substrates of depression and sickness behavior. Isr J Psychiatry Relat Sci 47: 64-71. Medline

Hauber W, Sommer S (2009) Prefrontostriatal circuitry regulates effortrelated decision making. Cereb Cortex 19:2240-2247. CrossRef Medline

Hockemeyer J, Burbiel JC, Müller CE (2004) Multigram-scale syntheses, stability, and photoreactions of A2A adenosine receptor antagonists with 8-styrylxanthine structure: potential drugs for Parkinson's disease. J Org Chem 69:3308-3318. CrossRef Medline

Hodgson RA, Bertorelli R, Varty GB, Lachowicz JE, Forlani A, Fredduzzi S, Cohen-Williams ME, Higgins GA, Impagnatiello F, Nicolussi E, Parra LE, Foster C, Zhai Y, Neustadt BR, Stamford AW, Parker EM, Reggiani A, Hunter JC (2009) Characterization of the potent and highly selective A2A receptor antagonists preladenant and SCH 412348 [7-[2-[4-2,4-difluorophenyl]-1piperazinyl]ethyl]-2-(2-furanyl)-7H-pyrazolo[4,3-e][1,2,4] triazolo[1,5c]pyrimidin-5-amine] in rodent models of movement disorders and depression. J Pharmacol Exp Ther 330:294-303. CrossRef Medline

Hudson AL, Lalies MD, Silverstone P (2012) Venlafaxine enhances the effect of bupropion on extracellular dopamine in rat frontal cortex. Can J Physiol Pharmacol 90:803-809. CrossRef Medline

Ishiwari K, Madson LJ, Farrar AM, Mingote SM, Valenta JP, DiGianvittorio MD, Frank LE, Correa M, Hockemeyer J, Muller C, Salamone JD (2007) Injections of the selective adenosine A2A antagonist MSX-3 into the nucleus accumbens core attenuate the locomotor suppression induced by haloperidol in rats. Behav Brain Res 178:190-199.
Kent TA, Preskorn SH, Glotzbach RK, Irwin GH (1986) Amitriptyline normalizes tetrabenazine-induced changes in cerebral microcirculation. Biol Psychiatry 21:483-491. CrossRef Medline

Keppel (1991) Design and analysis: a researcher's handbook, Ed 3. Upper Saddle River, NJ: Prentice-Hall.

Kitamura Y, Yagi T, Kitagawa K, Shinomiya K, Kawasaki H, Asanuma M, Gomita Y (2010) Effects of bupropion of the forced swim test and release of dopamine in the nucleus accumbens in ACTH-treated rats. Naunyn Schmiedebergs Arch Pharmacol 382:151-158. CrossRef Medline

Koch M, Schmid A, Schnitzler HU (2000) Role of nucleus accumbens (DA) D1 and D2 receptors in instrumental and Pavlovian paradigms of conditioned reward. Psychopharmacology 152:67-73. CrossRef Medline

Kurniawan IT, Seymour B, Talmi D, Yoshida W, Chater N, Dolan RJ (2010) Choosing to make an effort: the role of striatum in signaling physical effort of a chosen action. J Neurophysiol 104:313-321. CrossRef Medline

Mai B, Sommer S, Hauber W (2012) Motivational states influence effortbased decision making in rats: the role of dopamine in the nucleus accumbens. Cogn. Affect Behav Neurosci 12:74-84. CrossRef Medline

McGinty VB, Lardeux S, Taha SA, Kim JJ, Nicola SM (2013) Invigoration of reward seeking by cue and proximity encoding in the nucleus accumbens. Neuron 78:910-922. CrossRef Medline

Milea D, Guelfucci F, Bent-Ennakhil N, Toumi M, Auray JP (2010) Antidepressant monotherapy: a claims database analysis of treatment changes and treatment duration. Clin Ther 32:2057-2072. CrossRef Medline

Mingote S, Font L, Farrar AM, Vontell R, Worden LT, Stopper CM, Port RG, Sink KS, Bunce JG, Chrobak JJ, Salamone JD (2008) Nucleus accumbens adenosine A2A receptors regulate exertion of effort by acting on the ventral striatopallidal pathway. J Neurosci 28:9037-9046. CrossRef Medline

Mott AM, Nunes EJ, Collins LE, Port RG, Sink KS, Hockemeyer J, Müller CE, Salamone JD (2009) The adenosine A2A antagonist MSX-3 reverses the effects of the (DA) antagonist haloperidol on effort-related decision making in a T-maze cost/benefit procedure. Psychopharmacology 204:103112. CrossRef Medline

Nicola SM (2010) The flexible approach hypothesis: unification of effort and cue-responding hypotheses for the role of nucleus accumbens dopamine in the activation of reward-seeking behavior. J Neurosci 30:1658516600. CrossRef Medline

Nowend KL, Arizzi M, Carlson BB, Salamone JD (2001) $\mathrm{D}_{1}$ or $\mathrm{D}_{2}$ antagonism in nucleus accumbens core or dorsomedial shell suppresses lever pressing for food but leads to compensatory increases in chow consumption. Pharmacol Biochem Behav 69:373-382. CrossRef Medline

Nunes EJ, Randall PA, Santerre JL, Given AB, Sager TN, Correa M, Salamone JD (2010) Differential effects of selective adenosine antagonists on the effort-related impairments induced by (DA) D1 and D2 antagonism. Neuroscience 170:268-280. CrossRef Medline

Nunes EJ, Randall PA, Podurgiel S, Correa M, Salamone JD (2013a) Nucleus accumbens neurotransmission and effort-related choice behavior in food motivation: effects of drugs acting on dopamine, adenosine, and muscarinic acetylcholine receptors. Neurosci Biobehav Rev, in press.

Nunes EJ, Randall PA, Estrada A, Epling B, Hart E, Lee CE, Baqi Y, Müller CE, Correa M, Salamone JD (2013b) Effort-related motivational effects of the pro-inflammatory cytokine interleukin 1-beta: studies with the concurrent fixed ratio 5/ chow feeding choice task. Psychopharmacology, in press.

Pae CU, Lim HK, Han C, Patkar AA, Steffens DC, Masand PS, Lee C (2007) Fatigue as a core symptom in major depressive disorder: overview and the role of bupropion. Expert Rev Neurother 7:1251-1263. CrossRef Medline

Papakostas GI, Nutt DJ, Hallett LA, Tucker VL, Krishen A, Fava M (2006) Resolution of sleepiness and fatigue in major depressive disorder: A comparison of bupropion and the selective serotonin reuptake inhibitors. Biol Psychiatry 60:1350-1355. CrossRef Medline

Pardo M, Lopez-Cruz L, Valverde O, Ledent C, Baqi Y, Müller CE, Salamone JD, Correa M (2012) Adensoine A2A receptor antagonism and genetic deletion attenuate the effects of dopamine D2 antagonism on effort-related decision making in mice. Neuropharmacology 62:2068-2077.

Pasquereau B, Turner RS (2013) Limited encoding of effort by dopamine neurons in a cost-benefit trade-off task. J Neurosci 33:8288-8300. CrossRef Medline

Paxinos G, Watson C (1997) The rat brain in stereotaxic coordinates, Ed 3 [CD-ROM]. San Diego: Academic.

Pettibone DJ, Totaro JA, Pflueger AB (1984) Tetrabenazine-induced deple- 
tion of brain monoamines: characterization and interaction with selected antidepressants. Eur J Pharmacol 102:425-430. CrossRef Medline

Preskorn SH, Kent TA, Glotzbach RK, Irwin GH, Solnick JV (1984) Cerebromicrocirculatory defects in animal model of depression. Psychopharmacology 84:196-199. CrossRef Medline

Rampello L, Nicoletti G, Raffaele R (1991) Dopaminergic hypothesis for retarded depression: a symptom profile for predicting therapeutical responses. Acta Psychiatr Scand 84:552-554. CrossRef Medline

Randall PA, Pardo M, Nunes EJ, López Cruz L, Vemuri VK, Makriyannis A, Baqi Y, Müller CE, Correa M, Salamone JD (2012) Dopaminergic modulation of effort-related choice behavior as assessed by a progressive ratio chow task: pharmacological studies and role of individual differences. PLoS One 7:e47934. CrossRef Medline

Robbins TW, Everitt BJ (2007) A role for mesencephalic dopamine in activation: commentary on Berridge (2006). Psychopharmacology (Berl) 191:433-437. CrossRef Medline

Robertson GS, Vincent SR, Fibiger HC (1992) D1 and D2 dopamine receptors differentially regulate c-fos expression in striatonigral and striatopallidal neurons. Neuroscience 49:285-296. CrossRef Medline

Rosin DL, Robeva A, Woodard RL, Guyenet PG, Linden J (1998) Immunohistochemical localization of adenosine A2A receptors in the rat central nervous system. J Comp Neurol 401:163-186. CrossRef Medline

Salamone JD, Correa M (2002) Motivational views of reinforcement: implications for understanding the behavioral functions of nucleus accumbens dopamine. Behav Brain Res 137(1-2):3-25.

Salamone JD, Correa M (2012) The mysterious motivational functions of mesolimbic dopamine. Neuron 76:470-485. CrossRef Medline

Salamone JD, Steinpreis RE, McCullough LD, Smith P, Grebel D, Mahan K (1991) Haloperidol and nucleus accumbens (DA) depletion suppress lever pressing for food but increase free food consumption in a novel food choice procedure. Psychopharmacology 104:515-521. CrossRef Medline

Salamone JD, Cousins MS, Bucher S (1994) Anhedonia or anergia? Effects of haloperidol and nucleus accumbens (DA) depletion on instrumental response selection in a T-maze cost/benefit procedure. Behav Brain Res 65:221-229. CrossRef Medline

Salamone JD, Cousins MS, Snyder BJ (1997) Behavioral functions of nucleus accumbens (DA): empirical and conceptual problems with the anhedonia hypothesis. Neurosci Biobehav Rev 21:341-359. CrossRef Medline

Salamone JD, Arizzi MN, Sandoval MD, Cervone KM, Aberman JE (2002) Dopamine antagonists alter response allocation but do not suppress appetite for food in rats: contrast between the effects of SKF 83566, raclopride, and fenfluramine on a concurrent choice task. Psychopharmacology (Berl) 160:371380. CrossRef Medline

Salamone JD, Correa M, Mingote SM, Weber SM, Farrar AM (2006) Nucleus accumbens and the forebrain circuitry involved in behavioral activation and effort-related decision making: implications for understanding anergia and psychomotor slowing in depression. Curr Psychiatr Rev 2:267-280. CrossRef

Salamone JD, Correa M, Farrar A, Mingote SM (2007) Effort-related functions of nucleus accumbens and associated forebrain circuits. Psychopharmacology (Berl) 191:461-482. CrossRef

Salamone JD, Farrar AM, Font L, Patel V, Schlar DE, Nunes EJ, Collins LE, Sager TN (2009) Differential actions of adenosine A1 and A2A antagonists on the effort-related effects of D2 antagonism. Behav Brain Res 201:216-222. CrossRef Medline

Salamone JD, Correa M, Farrar AM, Nunes EJ, Collins LE (2010) Role of dopamine-adenosine interactions in the brain circuitry regulating effortrelated decision making: insights into pathological aspects of motivation. Future Neurol 5:377-392. CrossRef

Salamone JD, Nunes EJ, Randall PA, Huizenga M, Nowak V, Pardo M, Correa M (2012) Development of rodent models of the motivational symptoms of depression: Comparison of the effects of the monoamine depleting agents reserpine and tetrabenazine on effort-related decision making. Program No. 923.05. 2012 Neuroscience Meeting Planner, New Orleans, LA: Society for Neuroscience, Online.

Santerre JL, Nunes EJ, Kovner R, Leser CE, Randall PA, Collins-Praino LE, Lopez Cruz L, Correa M, Baqi Y, Müller CE, Salamone JD (2012) Behavioral studies with the novel adenosine A2A antagonist MSX-4: reversal of the effects of D2 antagonism. Pharmacol Biochem Behav 102:477-487. CrossRef Medline

Segovia KN, Correa M, Lennington JB, Conover JC, Salamone JD (2012) Changes in nucleus accumbens and neostriatal c-Fos and DARPP-32 im- munoreactivity during different stages of food-reinforced instrumental training. Eur J Neurosci 35:1354-1367. CrossRef Medline

Shafiei N, Gray M, Viau V, Floresco SB (2012) Acute stress induces selective alterations in cost/benefit decision-making. Neuropsychopharmacology 37:2194-2209. CrossRef Medline

Sink KS, Vemuri VK, Olszewska T, Makriyannis A, Salamone JD (2008) Cannabinoid CB1 antagonists and dopamine antagonists produce different effects on a task involving response allocation and effort-related choice in food-seeking behavior. Psychopharmacology 196:565-574. CrossRef Medline

Sokolowski JD, Salamone JD (1998) The role of nucleus accumbens dopamine in lever pressing and response allocation: Effects of 6-OHDA injected into core and dorsomedial shell. Pharmacol Biochem Behav 59:557-566.

Soskin DP, Holt DJ, Sacco GR, Fava M (2013) Incentive salience: novel treatment strategies for major depression. CNS Spectr 1:1-8. CrossRef Medline

Stahl SM (2002) The psychopharmacology of energy and fatigue. J Clin Psychiatry 63:7-8. CrossRef Medline

Svenningsson P, Le Moine C, Fisone G, Fredholm BB (1999) Distribution, biochemistry and function of striatal adenosine $\mathrm{A}_{2 \mathrm{~A}}$ receptors. Prog Neurobiol 59:355-396. CrossRef Medline

Svenningsson P, Nishi A, Fisone G, Girault JA, Nairn AC, Greengard P (2004) DARPP32: an integrator of neurotransmission. Annu Rev Pharmacol Toxicol 44:269-296. CrossRef Medline

Tanra AJ, Kagaya A, Okamoto Y, Muraoka M, Motohashi N, Yamawaki S (1995) TJS-010, a new prescription of oriental medicine, antagonizes tetrabenazine-induced suppression of spontaneous locomotor activity in rats. Prog Neuropsychopharmacol Biol Psychiatry 19:963-971. CrossRef Medline

Treadway MT, Zald DH (2011) Reconsidering anhedonia in depression: Lessons from translational neuroscience. Neurosci Biobehav Rev 35:537-555.

Treadway MT, Buckholtz JW, Schwartzman AN, Lambert WE, Zald DH (2009) Worth the 'EEfRT'? The effort expenditure for rewards task as an objective measure of motivation and anhedonia. PLoS One 4:e6598. CrossRef Medline

Treadway MT, Buckholtz JW, Cowan RL, Woodward ND, Li R, Ansari MS, Baldwin RM, Schwartzman AN, Kessler RM, Zald DH (2012a) Dopaminergic mechanisms of individual differences in human effort-based decision-making. J Neurosci 32:6170-6176. CrossRef Medline

Treadway MT, Bossaller NA, Shelton RC, Zald DH (2012b) Effort-based decision making in major depressive disorder: a translational model of motivational anhedonia. J Abnorm Psychol 121:553-558. CrossRef Medline

Trifilieff P, Feng B, Urizar E, Winiger V, Ward RD, Taylor KM, Martinez D, Moore H, Balsam PD, Simpson EH, Javitch JA (2013) Increasing dopamine D2 receptor expression in the adult nucleus accumbens enhances motivation. Mol Psychiatry

Walton ME, Bannerman DM, Alterescu K, Rushworth MF (2003) Functional specialization within medial frontal cortex of the anterior cingulate for evaluating effort-related decisions. J Neurosci 23:6475-6479. Medline

Wang H, Chen X, Li Y, Tang TS, Bezprozvanny I (2010) Tetrabenazine is neuroprotective in Huntington's disease mice. Mol Neurodegener 5:18. CrossRef Medline

Wardle MC, Treadway MT, Mayo LM, Zald DH, de Wit H (2011) Amping up effort: effects of d-amphetamine on human effort-based decisionmaking. J Neurosci 31:16597-16602. CrossRef Medline

Worden LT, Shahriari M, Farrar AM, Sink KS, Hockemeyer J, Müller CE, Salamone JD (2009) The adenosine A2A antagonist MSX-3 reverses the effort-related effects of (DA) blockade: differential interaction with D1 and D2 family antagonists. Psychopharmacology 203:489-499. CrossRef Medline

Yger M, Girault JA (2011) DARPP-32, jack of all trades... master of which? Front Behav Neurosci 5:56. CrossRef Medline

Yohn SE, Nunes EJ, Randall PA, Baqi Y, Müller CE, Correa M, Salamone JD (2012) Development of rodent models of the motivational symptoms of depression: The catecholamine depleting agent tetrabenazine affects effort-related decision making in the T-maze barrier choice task. Program No. 923.12. 2012 Neuroscience Meeting Planner, New Orleans, LA: Society for Neuroscience. Online. 